\title{
Isolation and characterisation of GTF2IRD2, a novel fusion gene and member of the TFII-I family of transcription factors, deleted in Williams-Beuren syndrome
}

\author{
Hannah J Tipney ${ }^{1}$, Timothy A Hinsley ${ }^{1,3}$, Andrew Brass ${ }^{2,3}$, Kay Metcalfe ${ }^{4}$, Dian Donnai ${ }^{4}$ and $^{2}$ \\ May Tassabehji ${ }^{*, 1}$ \\ ${ }^{1}$ University of Manchester, Academic Unit of Medical Genetics and Regional Genetic Service, St Mary's Hospital, \\ Manchester, UK; ${ }^{2}$ Department of Computer Science, University of Manchester, Oxford Road, Manchester, UK; ${ }^{3}$ School of \\ Biological Science, University of Manchester, Oxford Road, Manchester, UK; and ${ }^{4}$ Academic Unit of Medical Genetics \\ and Regional Genetics Service, St Mary's Hospital, Manchester, UK
}

Williams-Beuren syndrome (WBS) is a developmental disorder with characteristic physical, cognitive and behavioural traits caused by a microdeletion of $\sim 1.5 \mathrm{Mb}$ on chromosome 7q11.23. In total, 24 genes have been described within the deleted region to date. We have isolated and characterised a novel human gene, GTF2IRD2, mapping to the WBS critical region thought to harbour genes important for the cognitive aspects of the disorder. GTF2IRD2 is the third member of the novel TFII-I family of genes clustered on 7q11.23. The GTF2IRD2 protein contains two putative helix-loop-helix regions (I-repeats) and an unusual C-terminal CHARLIE8 transposon-like domain, thought to have arisen as a consequence of the random insertion of a transposable element generating a functional fusion gene. The retention of a number of conserved transposase-associated motifs within the protein suggests that the CHARLIE8-like region may still have some degree of transposase functionality that could influence the stability of the region in a mechanism similar to that proposed for Charcot-Marie-Tooth neuropathy type 1A. GTF2IRD2 is highly conserved in mammals and the mouse ortholgue (Gtf2ird2) has also been isolated and maps to the syntenic WBS region on mouse chromosome 5G. Deletion mapping studies using somatic cell hybrids show that some WBS patients are hemizygous for this gene, suggesting that it could play a role in the pathogenesis of the disorder.

European Journal of Human Genetics (2004) 12, 551-560. doi:10.1038/sj.ejhg.5201174

Published online 21 April 2004

Keywords: Williams-Beuren syndrome; CHARLIE8 transposase; deletion; TFII-I

\section{Introduction}

Williams-Beuren syndrome (WBS (MIM: \#19050)) is a rare developmental disorder (1/20000 live births)

*Correspondence: Dr M Tassabehji, University of Manchester, Academic Unit of Medical Genetics and Regional Genetic Service, St Mary's Hospital, Hathersage Road, Manchester, M13 0JH, UK.

Tel: + 44 (0)161 276 6608; Fax: + $44(0) 161276$ 6606;

E-mail: M.Tassabehji@man.ac.uk

Received 26 September 2003; revised 12 December 2003; accepted 7 January 2004 characterised by a number of striking physical and behavioural features. ${ }^{1}$ Individuals with WBS typically present with a distinctive dysmorphic face, mild growth retardation, supravalvular aortic stenosis (SVAS) and often infantile hypercalcemia. ${ }^{1}$ These physical traits are combined with an unusual pattern of mental abilities (Williams Syndrome Cognitive Profile, WSCP) encompassing both enhanced verbal abilities and limited visuospatial capabilities, with characteristic 'friendly' personality traits. ${ }^{2}$ 
WBS is the result of a chromosomal microdeletion (typically $\sim 1.5 \mathrm{Mb}$ in size) at 7q11.23 thought to arise as a consequence of unequal crossing over between highly homologous low-copy repeat (LCR) sequences flanking the deleted region. ${ }^{3}$ The majority of WBS patients have breakpoints, which cluster within these LCRs, but some possess atypical smaller deletions and consequently display partial phenotypes. ${ }^{4}$ Haploinsufficiency for elastin (ELN), the first gene identified in this region, causes the SVAS phenotype, ${ }^{5}$ lending support to the theory that individual genes located within the microdeletion are responsible for certain aspects of this complex syndrome.

The roles of many of the genes located in the WBS critical region have yet to be defined and their contribution to the pathology of WBS remains unclear, but recent work has been directed towards two I-repeat containing genes located near the telomeric end of the deletion breakpoints, which are invariably deleted in patients described with 'classic' WBS. ${ }^{6,7}$ GTF2I (or TFII-I) and GTF2IRD1 (or GTF3, MusTRD1, BEN, CREAM, WBSCR11) both contain multiple I-repeats that are novel domains of a helix-loop-helix-like structure. GTF2I contains both DNA and protein binding sites and is a multifunctional transcription factor that can bind enhancer (E-box) and core promoter elements (Inr). ${ }^{6}$ Similarly, GTF2IRD1 is also thought to have gene regulatory function through directed DNA interactions. ${ }^{7}$

In our ongoing effort to complete the WBS transcription map, we have identified a novel gene, GTF2IRD2, located within the WBS critical region on chromosome 7 . The mouse orthologue (Gtf2ird2) has also been isolated and maps to the syntenic mouse WBS region on chromosome 5G. We propose GTF2IRD2 to be the latest member of the Irepeat containing family of proteins (TFII-I family), comprising GTF2IRD1 and GTF2I (or TFII-I). GTF2IRD2 is, however, unusual because it has a C-terminal CHARLIE8 transposon-like motif thought to be a consequence of a random in-frame insertion of a transposable element that has generated a fusion gene. Here, we describe the characteristics and putative function of GTF2IRD2 in relation to WBS and the impact such a transposon-like element may have in this region. The location of GTF2IRD2 at the telomeric end of the WBS breakpoint, combined with its structural similarities to other genes in the WBS critical region (GTF2I and GTF2IRD1) and the novel C-terminal transposon-like element suggests that it has the potential to play a role in the pathogenesis of WBS.

\section{Materials and methods}

All primers described are summarised in Table 1. References 8-18 describe the bioinformatics tools utilised for the characterisation of GTF2IRD2.

\section{cDNA isolation}

A mouse Gtf2ird2 cDNA clone was isolated by screening a Stratagene mouse embryo cDNA library with a probe made from BAC 391016 (gb:AF267747). Hybridisation conditions were carried out according to the manufacturer's instructions (Stratagene) and repeats were competed out with placental DNA at a 100-fold concentration excess. Positive cDNA clones were sequenced by fluorescent BigDye terminator cycle sequencing (V 2.0 kit Applied Biosystems) using $\mathrm{T} 7$ and $\mathrm{T} 3$ vector primers, and visualised on an $\mathrm{ABI} 373$ sequencer.

GTF2IRD2 was isolated from an 18-week human foetal brain cDNA library (Gibco) screened with probes made from the mouse Gtf2ird2 cDNA. Hybridisation conditions were according to the manufacturer's instructions. Positive cDNA clones were sequenced using vector primers T7 and T3 as described above.

\section{Northern blot analysis}

Human and mouse Northern blots of poly(A) + RNA (Clontech) were probed with PCR products amplified from GTF2IRD2/Gtf2ird2 cDNA clones. Primers (GTF2IRD2 NTR/

Table 1 PCR primer sequences

\begin{tabular}{|c|c|c|}
\hline Human and mouse $P C R$ primers & Forward primer & Reverse primer \\
\hline GTF2IRD2 NTR & ATGGCCCAGGTAGCAGTGTCC & TATTTCCGTITCGCCCGAGTG \\
\hline GTF2IRD2 CTR & AGGCCGCTTCCAGGGCTTGAG & CGTGATCTCATCGATTGCGAT \\
\hline GAPDH & ACAGTCAGCCGCATCTTCTT & GACAAGCTTCCCGTTCTCAG \\
\hline Gtf2ird2 $\times 3 \mathrm{~F}-\mathrm{X} 4 \mathrm{R}$ & GTGTAAAGAGCTGGCCAAGTCC & СTGCACGGCTCTCСTGAGCAGCTC \\
\hline Gtf2ird2 CTR & СТTCСTGGACTTGAACTCAGT & TCGTCATGTCCACTAGGAAGG \\
\hline Gapdh & СССАСТААСАТСАААТGGGG & ССТТССАСААТGССАААGТТ \\
\hline STSG12617 & CTAGGCTGAGGTCTTATTGTTGG & GAACATATGACTCTGTAGAAAGC \\
\hline FKBP6 X8 & СТСТTGACСАТСТGССТTССС & ССTGGGTGTTTATTCCCAAGTCAC \\
\hline ELN X2 & TCCATGTAATTGTGGGTTTTGCC & САATGTTCСТАССТTСТGTAGTG \\
\hline GTF2I X10 & AGCTTCCAAATAGAAGCGTTGTA & TTCCСATAGGCTTTATTAATCAG \\
\hline GTF2I $3^{\prime}$ & CTACATAACCTAGATAACCTAAC & TATGCAGGGGGTTCAGATGGACA \\
\hline GTF2IRD2 I7 & ATTAAACGTGTCTACCGAAAG & AAATCCACAАСТАТGCACAGC \\
\hline GTF2IRD2 I1 & TATСТАТСССАААТGTGTССТTG & GCTATGAAATGTATTCTCTGCGG \\
\hline GTF2IRD $2 \beta$ & CGGGCTATGAAATGTATTCTCTG & AAGTTTATCTATCССAAATGGTG \\
\hline CALN15' & GССТСТGTGATСТСТGССAGGG & CAGCCCAGGAAGTTTCTAGAAGC \\
\hline
\end{tabular}


CTR and Gtf2ird2 $\times 3$ F-4R/CTR) were designed to exclude the I-repeat regions and to avoid cross hybridisation with similar genes. Hybridisation conditions were according to the manufacturer's instructions

\section{RT-PCR analysis}

Total RNA $(1 \mu \mathrm{g})$ from each tissue was reverse transcribed using a first-strand cDNA synthesis kit (Promega). Primers designed from specific regions (GTF2IRD2 NTR/CTR and Gtf2ird $2 \times 3 \mathrm{~F}-4 \mathrm{R} / \mathrm{CTR}$ ) were used to look for expression by RT-PCR of the cDNA. PCR conditions were $50 \mathrm{ng}$ of cDNA, 10 pmol of each primer and $0.5 \mathrm{U}$ Taq polymerase (BCL) in the manufacturer's buffer for a $20 \mu \mathrm{l}$ reaction. Cycling conditions were $2 \mathrm{~min}$ denaturation at $94^{\circ} \mathrm{C}$, followed by 35 cycles of $94^{\circ} \mathrm{C} 1 \mathrm{~min}, 55^{\circ} \mathrm{C} 1 \mathrm{~min}, 72^{\circ} \mathrm{C} 1 \mathrm{~min}$ and $5 \mathrm{~min}$ extension at $72^{\circ} \mathrm{C}$. The integrity of the RNA was assessed by PCR analysis of the human GAPDH or mouse Gapdh gene. All primers were cDNA specific and spanned exon-intron boundaries to avoid amplification of contaminating DNA.

Deletion mapping of WBS somatic cell hybrids by PCR The study was approved by the institutional review board. Hybrid cell lines containing the deleted chromosome 7 homologues were prepared from four patients with 'classic' WBS phenotypes, by fusion of the patient's lymphoblastoid cells with mouse BW5147 cells as described previously. ${ }^{4}$ The deletion status of WBSCR genes (primer sequences in Table 1) was determined by PCR analysis of DNA from the somatic cell hybrids. Specific GTF2IRD2 primers (GTF2IRD2 I7/I1 GTF2IRD2 $\beta$ ) were designed by incorporating specific nucleotide differences identified in the intron sequences. Primers for the CALN1 gene were included as an internal nondeleted PCR control. Negative controls included mouse genomic DNA. PCR conditions were $50 \mathrm{ng}$ of DNA, 10 pmol of each primer and $0.5 \mathrm{U}$ Taq polymerase (BCL) in the manufacturer's buffer, for a $20 \mu \mathrm{l}$ reaction.
Cycling was at 2 min denaturation at $94^{\circ} \mathrm{C}$, followed by 30 cycles of $94^{\circ} \mathrm{C} 1 \mathrm{~min}, 55^{\circ} \mathrm{C} 1 \mathrm{~min}, 72^{\circ} \mathrm{C} 1 \mathrm{~min}$, with a final 5 min extension at $72^{\circ} \mathrm{C}$.

\section{Results \\ Mus musculus Gtf2ird2 structure and properties}

Mouse Gtf2ird2 cDNA clones were isolated by screening a Stratagene mouse embryo cDNA library with the BAC 391016 (AF267747). The largest cDNA was 3468 bp in size and gave a predicted ORF of 936 amino-acid residues from the first predicted methionine start codon (in exon 2) (sequence submitted to GenBank: AY014963). The genomic structure of Gtf2ird2 was defined using the mouse BAC 391016 sequence (gb: AF267747) (see Table 2). Gtf2ird2 spans a genomic region of $33940 \mathrm{bp}$ and is composed of 16 exons ranging from 29 to $1573 \mathrm{bp}$ in size. All the exonintron junctions conform to the consensus splice sequences. Two polyadenylation signals were identified 107 and 412 bp downstream from the termination codon (TAG) located in exon 16. Repeat masking program analysis ${ }^{15}$ of the cDNA sequence showed it to be composed of $46.86 \%$ (1619 bp) interspersed repeats: $2.92 \%$ were SINE/Alus (bases 20-116) and 43.94\% were MER1_type (CHARLIE8) DNA element (bases 1457-1693 and 1716-2996).

FISH analysis using BAC 391016 suggests that there is a single copy of Gtf2ird2 residing on mouse chromosome 5G (data not shown) situated in a $5^{\prime}-3^{\prime}$ orientation $3618 \mathrm{bp}$ proximal to the $N c f 1$ gene (calculated from genomic sequence gb: AF267747).

A Northern blot comprising adult mouse tissues hybridised with Gtf2ird2 cDNA probes displayed a strongly expressed transcript of approximately $3.5 \mathrm{~kb}$ in heart, brain and liver. Weaker bands were detected in spleen, lung, kidney and skeletal muscle. A smaller transcript $(\sim 3 \mathrm{~kb})$ was detected in testis suggesting that a splice isoform of

Table 2 Mus musculus Gtf2ird2 genomic structure showing exon/intron sizes and boundaries

\begin{tabular}{|c|c|c|c|c|}
\hline Exon & $5^{\prime}$ terminus & Exon size $(b p)$ & $3^{\prime}$ terminus & Intron size (bp) \\
\hline 1 & GCTTCGGCCACGCGCGGGAA & 220 & AGGGCCCTCAGgtgcgtatc & 6921 \\
\hline 2 & tcctctacagGAACAATGGC & 98 & GGAGTCCATGgtgagacgct & 1380 \\
\hline 3 & tctgtttcagTGTAAAGAGC & 139 & GCACAGCACTgtaggtggCC & 2069 \\
\hline 4 & gtgtttgcagGCCAGGGGGA & 117 & CTCTGTTACCgtgagtccct & 1444 \\
\hline 5 & cctgtcctagGTAAAGCCTT & 184 & CTGTAAAGAGgtaatctgct & 642 \\
\hline 6 & tttcttgcagGCССТTССТА & 29 & AGCCAGCTGGgtaagtagcg & 4126 \\
\hline 7 & tcttgcacagGTGGCCTTGG & 56 & CAAATGACAGgttaaaaaaa & 612 \\
\hline 8 & ctccttgcagCTATGGCCCT & 44 & GAAGATTCTGgtaggtacac & 988 \\
\hline 9 & gccetcatagGCACTTCACC & 78 & AACGTGCAAGgtaatgcggt & 3422 \\
\hline 10 & ctcctttcagGAAGCCAGCA & 57 & CСATCTGAAGgttagaaaас & 2048 \\
\hline 11 & tctttttaagAGTCTACTCG & 63 & AAAATGGAAGgtgagtcacc & 2255 \\
\hline 12 & tgctctcaagGAAATGCAAG & 78 & ACAGTCGCAGgtggggacat & 1776 \\
\hline 13 & ttatttgtagATAATGAGAA & 84 & CGCAAGTITGgtaagtttct & 831 \\
\hline 14 & ctcatcacagGGGAGGCGAT & 184 & CGGTCATTAGgtgagtgagt & 494 \\
\hline 15 & ctccctgcagACCACТТССТ & 29 & CTCAGTAATGgtgagtattt & 1464 \\
\hline 16 & ctctataaagTGGGGAAACG & 1573 & GGTGGCCACGTGÄcagagcagagg & -- \\
\hline
\end{tabular}


Gtf2ird2 exists in this tissue. RT-PCR on a panel of mouse cDNAs using primers specific for the $\mathrm{N}$ - and C-termini showed that Gtf2ird2 was expressed in all the tissues tested, with significantly lower levels detected in heart, muscle, skin and bone (Figure 1a and b). There was no obvious expression in whole mouse embryo cDNA (E9.5 and $10.5 \mathrm{dpc})$.

\section{Human GTF2IRD2 structure and properties}

The largest human GTF2IRD2 cDNA clone isolated from a human foetal brain cDNA library was $3559 \mathrm{bp}$ in length with a predicted ORF 949 amino-acid residues (sequence submitted to GenBank: AY312850). Blast analysis of this cDNA sequence identified a number of genomic clones mapping to the WSCR with excellent homology, but only the sequence in BAC RP11-219M8 (gb: AC124781) was identical to the GTF2IRD2 cDNA we isolated. Sequence alignments allowed the genomic structure of GTF2IRD2 to be defined (see Table 3): it contains 16 exons comparable to those in the murine homologue, with all the intron/exon boundaries conforming to the consensus splice donor and acceptor sequences. Human GTF2IRD2 spans a genomic region of $57251 \mathrm{bp}$ and lies in a $3^{\prime}-5^{\prime}$ orientation $6822 \mathrm{bp}$ distal to the NCF1 gene. RepeatMasker ${ }^{15}$ analysis of the cDNA sequence identified a total of $2146 \mathrm{bp}(60.30 \%)$ of interspersed repeats. In all, 8.32\% were ALUs, $1.46 \%$ were low complexity repeats and $50.52 \%$ (1798bp) was a MER1_type (CHARLIE8) DNA element located at the Cterminus.

Northern blot analysis identified a GTF2IRD2 transcript of $\sim 3.5 \mathrm{~kb}$ with ubiquitous expression in the tissues tested (heart, brain, liver, pancreas, placenta and lung). This pattern was confirmed by RT-PCR analysis on a larger range of tissues (Figure 1). Higher levels of GTF2IRD2 appear to be expressed in foetal tissue compared with adult tissues with weak expression in skin fibroblasts.

\section{Predicted GTF2IRD2 protein properties}

GTF2IRD2 appears to be a slightly acidic protein (calculated pI of 5.8) with a molecular weight of $107233 \mathrm{Da}(936$ Aa) and two discrete regions of predominantly hydrophilic residues (residues: 235-269 and 458-496) (Figure 2). Protein secondary structure analysis suggests a predominantly helical structure. ${ }^{18}$ It is also predicted to be soluble and located in the cytoplasm (77\% probability). ${ }^{14}$ No signal peptide cleavage site was identified using the SignalP v1.1 program. ${ }^{16}$ Potential post-translational modifications include four N-glycosylation sites (residues: 156-159 NYSL; 204-207 NDSY; 465-468 NHSR; 552-555 NDTT) and multiple putative phosphorylation sites for all the major protein kinases including two tyrosine phosphorylation sites (residues: $235-243,236-244) .{ }^{12,14}$

The sequence divides into two halves: the N-terminal 410 amino acids show high homology to the TFII-I family of transcription factors (GTF2I and GTF2IRD1) and contain two I-repeats (PF02946, IPR004212) (residues: 107-185 and $332-410)$. The majority of the identity shared between GTF2IRD1 and GTF2IRD2 is located around the I-repeats with little conservation in the remaining sequence. The $\mathrm{N}$ terminus of GTF2IRD2 (residues 1-410) has 75\% identity and $84 \%$ similarity with GTF2I (see Figure 3). The Cterminal sequence (residues 414-949) of GTF2IRD2 share high identity $(>78 \%)$ to the CHARLIE8 transposable element.

\section{DNA and protein binding capabilities of GTF2IRD2} GTF2IRD2 has numerous putative sites thought to be capable of facilitating DNA and protein interactions. An
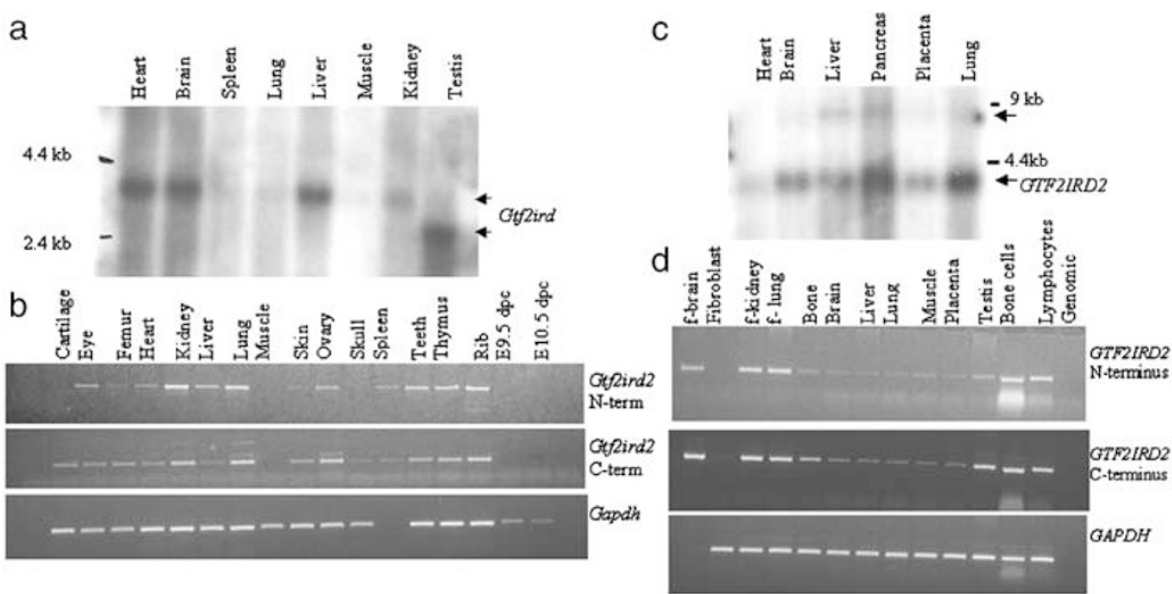

Figure 1 Expression analysis of mouse and human GTF2IRD2. (a) Mouse Northern blot analysis showing a Gtf2ird2 transcript of $\sim 3.5 \mathrm{~kb}$. A smaller transcript is present in mouse testis. (b) RT-PCR analysis shows Gtf2ird2 expression in all adult mouse tissues. (c) Human Northern blot analysis showing a GTF2IRD2 transcript of $\sim 3.5 \mathrm{~kb}$ in all tissues tested. (d) RT-PCR analysis shows ubiquitous GTF2IRD2 expression in all human tissues, but at very low levels in skin fibroblasts. 
Table 3 Human GTF2IRD2 genomic structure showing intron/exon sizes and boundaries

\begin{tabular}{|c|c|c|c|c|c|c|}
\hline Exon & Includes & $5^{\prime}$ terminus & $5^{\prime}$ splice site & Exon size $(b p)$ & $3^{\prime}$ terminus & Intron size (bp) \\
\hline 1 & $5^{\prime}$ UTR & $1-185$ & GGAAAAGGGGGGGAA & 185 & CTCAGgtgcgtaccc & 16195 \\
\hline 2 & $\operatorname{ATG}(191) \mathrm{LZ}$ & $186-289$ & tcttgcacagGGATC & 104 & CCATGgtgagacagc & 3335 \\
\hline 3 & $\mathrm{LZ}$ & $290-428$ & tctgtttcagTGTAA & 139 & ATACTgtaggtgttt & 8362 \\
\hline 4 & 1st I-repeat & $429-548$ & ccatttgcagGCGTT & 120 & TTATGgtaacgttca & 2125 \\
\hline 5 & 1st I-repeat & $549-732$ & cttcttgtagGTAAA & 184 & AATAGgtgacacact & 168 \\
\hline 6 & 1st I-repeat & $733-761$ & tttcttgcagACCCC & 29 & GCTGGgtaagtgaca & 2399 \\
\hline 7 & -- & $762-816$ & tcctctacagGTGGC & 85 & GAAAGgtaaaagata & 371 \\
\hline 8 & -- & $817-860$ & ctccttgcagCTGCG & 44 & TTCTGgtgggtacca & 6756 \\
\hline 9 & -- & $861-938$ & acattccaagGCATT & 78 & GCAAGgtaatactgt & 1790 \\
\hline 10 & -- & $939-995$ & tttctttcagGAAGC & 57 & GGAAGgttagaaaaa & 1724 \\
\hline 11 & -- & $996-1061$ & ttttttcaagATTCC & 66 & CGAAGgttagttgcc & 2100 \\
\hline 12 & -- & $1062-1139$ & ctgttttaagGAAAC & 78 & TCCAGgtatggacta & 2074 \\
\hline 13 & 2nd I-repeat & $1140-1223$ & ttatttttagATAAT & 84 & ATTTGgtaagttttt & 1294 \\
\hline 14 & 2nd I-repeat & $1224-1407$ & cccgtcacagGTGAA & 184 & ATCAGgtaagtgagt & 1283 \\
\hline 15 & 2nd I-repeat & $1408-1436$ & ttctcttcagGCCGC & 29 & TAATGgtgagtattc & 3713 \\
\hline 16 & CHARLIE8-like region & $1437-3559$ & ctgtcaaaagTGGGA & 2113 & CAACGTGAtggagagaaa & -- \\
\hline
\end{tabular}

N-terminal leucine zipper (LZ) motif, situated before the first I-repeat at amino-acid residues $23,30,37,44$ (VLLV), is thought to aid the formation of dimers. ${ }^{19}$ A BED zincfinger DNA binding motif (PF02892) was identified at positions $435-471 .^{11}$ The BED zinc-finger motif of 50-60 residues comprised of conserved cystines and histidines $\left(\mathrm{C} x_{2} \mathrm{C} x_{n} \mathrm{H} x_{3-5}[\mathrm{H} / \mathrm{C}]\right),{ }^{20}$ and an N-terminal conserved tryptophan motif. In GTF2IRD2, the metal chelating motif is clearly visible (residues 447, 450, 465 and 470,) but the N-terminal, mainly aromatic, motif is slightly less well preserved with three (amino acids 432, 433, 435) of the five key residues conserved (Figure 3 ). A region of basic residues (KRK) N-terminal to the BED motif at positions $418-420$ is thought to interact with the minor groove of DNA, while the rest of the BED structure associates with the major groove. ${ }^{20}$ In addition, GTF2IRD2 has a C-terminal CHARLIE8 transposon-like element of 534 residues. The CHARLIE8 transposon (or MER102) (1) $^{21}$ an autonomous mammalian-specific member of the MER1 transposase family $^{22}$ characterised by an $8 \mathrm{bp}$ palindromic insertion site and two flanking Terminal Inverted Repeats (TIRs 15 bp consensus sequence: CAGgGGTCCCCAACC). ${ }^{23}$ Most transposable elements are autonomous and transposition is catalysed by the transposase encoded by the element itself. The transposase functions by binding TIRs flanking the transposable element and then cleaving the DNA to excise the element, leaving a characteristic footprint behind (a $16 \mathrm{bp}$ duplication of the $8 \mathrm{bp}$ target site). To determine if the integrated CHARLIE8 transposon-like element could still be functional, GTF2IRD2 and the surrounding genomic sequence was screened for three transposase-related domains:

(i) MER1 TIR sequences: two putative sites flanking the CHARLIE8-like element were identified - one in the genomic sequence $\sim 3922$ bp upstream of GTF2IRD2 $3^{\prime}$
UTR and one in intron 15 approximately $137 \mathrm{bp}$ upstream from exon 16.

(ii) the 'third region' is a motif required for the transposase ability of members of the hAT transposase family; ${ }^{24}$ this motif was detected at amino-acid residues $884-949$.

(iii) an atypical $\mathrm{D}, \mathrm{D}(35) \mathrm{E}$ domain $(\mathrm{D}, \mathrm{D}(34) \mathrm{E})$, which is the DNA cleavage and excision active site; ${ }^{25}$ this motif was detected at residues 748,782 and 816 with conserved spacing between the residues.

The genomic sequence between NCF1 3'UTR and GTF2IRD2 3'UTR was also analysed using exon prediction packages (MZEF, FEX and Hexon) to identify the rest of the original gene disrupted by the CHARLIE8-like transposase, however, no obvious partial transcripts were detected. The CHARLIE8 transposon-like motif appears to be present only on chromosome 7 . Other putative fusion genes described with similar architecture to GTF2IRD2 (ie a cellular gene comprising of an N-terminal hAT transposase-like element) include: Buster1 (NP_067034) on chromosome 11p15.3 and Buster3 (NP_071373) on chromosome 5q34. Both genes have unknown functions but are thought to be 'fusion genes' created by random inframe insertions of hAT transposase-like mobile elements. $^{22}$

Similar analyses on the mouse Gtf2ird2 protein identified a BED finger motif (KRK) at residues $414-416$ with the $\mathrm{N}$-terminal, mainly aromatic, residues (WCCHH at residues 428, 442, 445, 460 and 465), and an atypical DDE domain (residues 742, 776 and 810). No 'third region' was detected.

\section{Duplication of GTF2IRD2 in the human WBSCR}

The deletion in WBS is flanked by low copy repeats ${ }^{3}$ and since GTF2IRD2 maps within this duplicated region, more than one copy of the gene was identified by database 
1 gggaaagaaagaaagagaaaaaggagggcgagtggcgagcaggggectcggecgccaccc

62 cacgeccegaagcgtgetcgteccecgegeggggetcceggecgecgecetcggecatcg

122 gctgetccecggtggecaggectcggactccgeggecggeccggegeggeccagcgece

182 tcagggatcatggeccaggtagcagtgtccaccetgcetgttgaagaagagtcctcctca

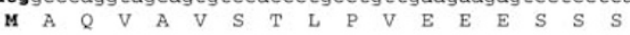

242 gagaccaggatggtggtgacattcctcgtgtctgecctcgaatccatgtgtaaagaactg

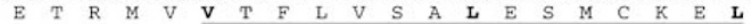

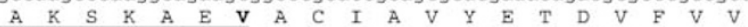

362 ggaaccgagagaggatgcgcttttgttaatgccaggacggattttcagaaagattttgca G T E R G C A F V N A R T

422 aatactgcgttgcagagggactgtgtgaggtgaaacctccctgccetgtgaacgggatg

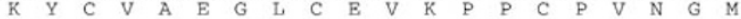

482 caggtccactcgggcgaaacggaaatactcaggaaggcagtggaggactatttctgctt

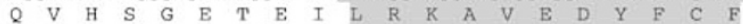

542 tgttatggtaaagccttagggacaacagtgatggtgectgttcctatgagaagatgctg C $\begin{array}{lllllllllllllllllll} & \text { K } & \text { K } & \text { A } & \text { L } & \text { G } & \text { T } & \text { T } & \text { V } & \text { M } & \text { V } & \text { P } & \text { V } & \text { P } & \text { Y } & \text { E } & \text { K } & \text { M } & \text { L }\end{array}$

603 cgagaccagtcggetgtggtagtgcaggggettccggaaggcgttgcetttcaacaccet

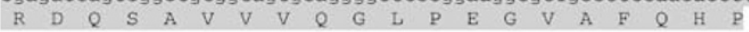

662 gagaattacgaccttgcaaccetgaaatggattttggagaacaaagcagggatttcatte E $N$ N $\quad$ Y

722 atcataaatagaccettcctaggaccagagagtcagctgggtggecctgggatggtaaca

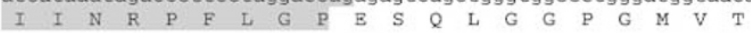

782 gatgcggagagatccatagtatcaccaagtgaaagetgcggeccatcaatgtgaaaact $\begin{array}{llllllllllllllllllll}\mathrm{D} & \mathrm{A} & \mathrm{E} & \mathrm{R} & \mathrm{S} & \mathrm{I} & \mathrm{V} & \mathrm{S} & \mathrm{P} & \mathrm{S} & \mathrm{E} & \mathrm{S} & \mathrm{C} & \mathrm{G} & \mathrm{P} & \mathrm{I} & \mathrm{N} & \mathrm{V} & \mathrm{K} & \mathrm{T}\end{array}$

842 gaacccatggaagattctggcatttcactgaaagcagaagctgtctcagtcaagaaagaa

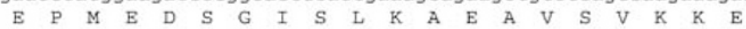

902 tcagaagatcctaattactatcaatataatatgcaaggaagccacccttcttccacaagc

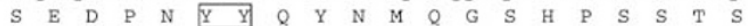

962 aatgaagtaatagaaatggaattaccaatggaagattccactccgctggtcccttcagaa

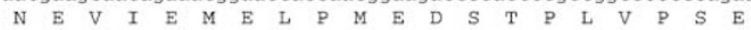

1022 gaaccaaatgaggacctgaagccgaggtgaaaatcgaaggaaacacaaattcatccagt $\begin{array}{lllllllllllllllllllll} & E & P & N & E & D & P & E & A & E & V & K & I & E & G & N & T & N & S & S & S\end{array}$

1082 gttacaaattctgcagcaggtgttgaagatcttaacatcgttcaagtgactgttccagat $\begin{array}{lllllllllllllllllllll}\text { V } & \text { T } & \text { N } & \text { S } & \text { A } & \text { A } & \text { G } & \text { V } & \text { E } & \text { D } & \text { L } & \text { N } & \text { I } & \text { V } & Q & \text { V } & \text { T } & \text { V } & \text { P } & \text { D }\end{array}$

1142 aatgagaaggaaagattatcaagcattgaaaagattaaacagctaagagaacaagttaat

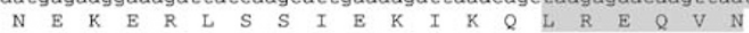

1202 gacctctttagccgaaaatttggtgaagcaattggcgtggatttccctgtgaaagttccc D $\quad$ L

1262 tacaggaagatcacattcaaccctggctgtgtggtgattgatggcatgccccgggggtg

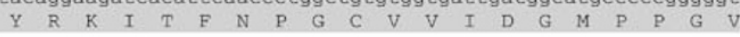

1322 gtattcaaggccccggctatctggaaatcagttccatgaggaggatcttggaggcagct

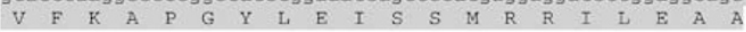

1382 gagtttatcaaattcacagtcatcaggcegcttccagggettgagctcagtaatgtggga

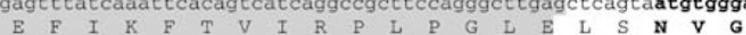

1442 aaacgcaagatagaccaggagggecgtgtgtttcaagaaaagtgggagagagcgtatttc $\begin{array}{llllllllllllllllllllll}K & R & \text { K } & \text { I } & \text { D } & Q & \text { E } & G & \text { R } & \text { V } & F & Q & E & K & \text { W } & \text { E } & R & \text { A } & Y & F\end{array}$ 1502 ttcgtggaagtacagaatattccaacatgtctcatatgcaaacaaagcatgtctgtgtcc

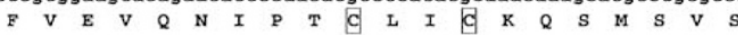
562 aaagaatataacctaagacgccactatcaaaccaatcacagcaagcattatgaccagtat $\begin{array}{lllllllllllllllllllll}K & E & Y & N & L & R & R & H & Y & Q & T & N & \text { A } & \text { S } & \text { S } & K & H & Y & D & Q & Y\end{array}$

1622 acggaaagaatgcgtgacgagaagcttcacgagctgaaaaagggctcaggaagtatctc $\begin{array}{lllllllllllllllllllllll} & \text { T } & E & R & M & R & D & E & K & L & H & E & L & K & K & G & L & R & K & Y & L\end{array}$

1682 ttaggctcgtcagacaccgagtgtccegagcaaaaacaagtgtttgcaaacccaagtcca $\begin{array}{llllllllllllllllllllll}\text { L } & G & S & S & D & T & E & C & P & E & Q & K & Q & V & F & A & N & P & S & P\end{array}$

1742 acccagaaatccccgtgcagcetgtagaggacctagctgggaacttatgggagaagtta $\begin{array}{lllllllllllllllllllll} & T & Q & K & S & \text { P } & \text { V } & Q & \text { P } & \text { V } & \text { E } & \text { D } & \text { L } & \text { A } & \text { G } & \text { N } & \text { L } & \text { W } & \text { E } & \text { K } & \text { L }\end{array}$

1802 cgtgaaaaatcaggtcttttgtggcatattctatcgcaatcgatgagatcacggatata $\begin{array}{lllllllllllllllllll}R & E & K & I & R & S & F & V & A & Y & S & I & A & I & D & E & I & T & D\end{array}$

1862 aataataccaccagttggccatattcatccgtggtgtcgatgagaatttcgatgtgtcc

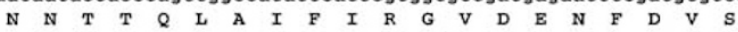

1922 gaagaacttctggacacggtgcccatgacgggtacaaaatctggcaacgagatctttttg $\begin{array}{llllllllllllllllllllll} & E & E & L & \text { L } & \text { D } & \text { T } & \text { V } & \text { P } & \text { M } & \text { T } & \text { G } & \text { T } & \text { K } & \text { S } & G & \text { N } & \text { E } & \text { I } & F & \text { I }\end{array}$

1982 cgtgttgagaagagcctgaaaaagttctgtatcaactggtcgagattagtaagcgtggcc $\begin{array}{llllllllllllllllllll}R & V & E & K & S & L & K & K & F & C & I & \text { N } & \text { W } & S & R & L & V & S & V & A\end{array}$

2042 tccactggcacccagegatggtggatgccaataacgggettgtcacaaaactgaagtcc $\begin{array}{llllllllllllllllllll}\mathbf{S} & \text { T } & \text { G } & \text { T } & \text { P } & \text { A } & \text { M } & \text { V } & \text { D } & \text { A } & \text { N } & \text { N } & \text { G } & \text { L } & \text { V } & \text { T } & \text { K } & \text { L } & \text { K } & \text { S }\end{array}$

2102 agggtggcgacgttctgcaagggtgcggaactgaagtccatctgttgtataattcatccg

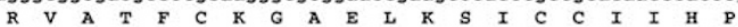

2162 gaatcactctgtgctcagaagttgaagatggaccacgtcatggacgtggtagtgaagtcc

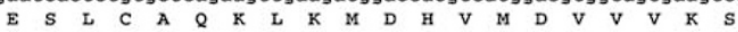

2222 gtgaactggatatgctcceggggactgaaccacagcgagttcacaaccttgctctatgag

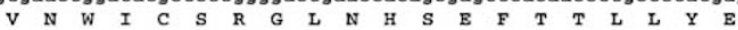

2282 ctggacagccagtatggtagcctcctgtactacacggagattaagtggctcagtcgcggg $\begin{array}{llllllllllllllllllllll}\text { L } & \text { D } & \text { S } & Q & \text { Y } & G & \text { S } & \text { L } & \text { L } & \text { Y } & \text { Y } & \text { T } & \text { E } & \text { I } & \text { K } & \text { W } & \text { L } & \text { S } & \text { R } & G\end{array}$

2342 ctcgtgctaaagagatttttcgaatccttggaagaaatcgactccttcatgtcatccaga L V L K R F F E S L E E I D S F M S S R

2402 gggaaaccctgectcaactgagctccatagattggatccgagacctggecttcttggtt $\begin{array}{llllllllllllllllllll}G & K & P & L & P & Q & L & S & S & I & D & W & I & R & D & L & A & F & L & V\end{array}$

2462 gacatgacgatgcatctgaacgetttgaacatctctctccaaggacactcccaaatcgtc D M T M H L

2522 acgcagatgtatgacctgatccgggcgttcctagcaaaactgtgcctctgggagactcat

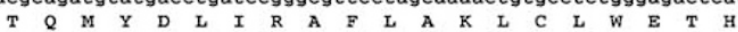

2582 ttgacgaggaataatctggcccactttcccaccetgaaattggtttccagaaatgaaagc $\begin{array}{lllllllllllllllllllllll}\text { L } & T & R & N & N & L & A & H & F & P & T & L & K & L & \text { V } & \text { S } & \text { R } & \text { N } & \text { E } & S\end{array}$

2642 gatggcctgaactacattcccaaaatcgcggaactcaagaccgaattccagaaaaggct

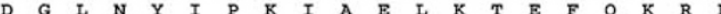

2702 tctgatttcaaactctacgaaagcgaactgactctgttcagctcccgttctccacgaag

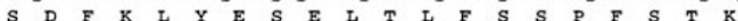

2762 atcgacagtgtgcacgaggagctccagatggaggttatcgacctgcaatgcaacacggtc $\begin{array}{llllllllllllllllllll}I & D & S & V & H & E & E & L & Q & M & E & V & I & D & L & Q & C & N & T & V\end{array}$

2822 ctgaagacgaaatacgacaaggtgggaataccagaattctacaagtacctctggggtagc $\begin{array}{lllllllllllllllllllll}\mathrm{L} & \mathrm{K} & \mathrm{T} & \mathrm{K} & \mathrm{Y} & \mathrm{D} & \mathrm{K} & \mathrm{V} & \mathrm{G} & \mathrm{I} & \mathrm{P} & \mathbf{E} & \mathbf{F} & \mathrm{X} & \mathrm{K} & \mathrm{Y} & \mathrm{L} & \mathrm{W} & \mathrm{G} & \mathrm{S}\end{array}$

2882 tacccgaaatacaagcaccattgcgcaaagattctttccatgttcgggagcacctacatc $\begin{array}{llllllllllllllllllll}\mathrm{Y} & \mathrm{P} & \mathrm{K} & \mathrm{Y} & \mathrm{K} & \mathrm{H} & \mathrm{H} & \mathrm{C} & \mathrm{A} & \mathrm{K} & \mathrm{I} & \mathrm{L} & \mathrm{S} & \mathrm{M} & \mathrm{F} & \mathrm{G} & \mathrm{S} & \mathrm{T} & \mathrm{Y} & \mathrm{I}\end{array}$

Figure 2 GTF2IRD2 $\beta$ cDNA Sequence. Full-length sequence and annotated translation of GTF2IRD2 $\beta$ cDNA. Start is in bold text. The putative Leucine Zipper region is underlined with the residues implicated in bold text (VLLV). Two I-repeats are highlighted in grey, the CHARLIE8-like element (nucleotide 1434-3560) is in boldface. Predicted tyrosine phosphorylation sites (residues 243 and 244) are boxed. Amino-acid residues $(478,500,597,609,612,812)$ that differ in GTF2IRD2 $\beta$ and GTF2IRD2 are boxed. $q$ indicates the BED zinc-finger DNA binding motif (at residue positions 435-471); the conserved aromatic and tryptophan motif (residues 418-429, 432) and the conserved cystine/histidine pattern $\left(\mathrm{C} x^{2} \mathrm{C} x_{n} \mathrm{H} x_{3-5}[\mathrm{H} / \mathrm{C}]\right.$, residues $447-470)$. The atypical $D, D(34) E$ domain residues $(748,782$ and 816$)$ are highlighted with an asterisk $\left({ }^{*}\right)$. No polyA signal was detected in the CDNA sequence. 


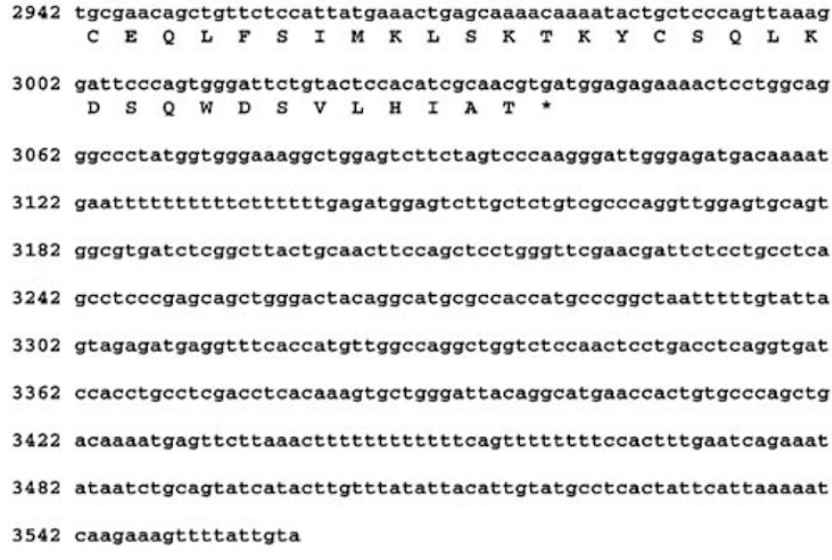

Figure 2 Continued

mining (predominantly BLAST searches). Alignment of all the GTF2IRD2 sequences together suggests that there could be three full-length transcript variants and a pseudogene, at different loci around the WBSCR (see Figure 4).

(i) The GTF2IRD2 gene (gb: AY312853) resides in the genomic clones BAC 239C10 (gb: AC004166) and PAC RP4-771P4 (gb: AC004883)) and is supported by cDNA clone evidence (clone DKFZp434O1635 gb: AL834153).

(ii) GTF2IRD2 $\alpha$ (gb: AY312854) lies in BAC RP11-813J7 (gb: AC083884) and is supported by a recently submitted cDNA clone (gb: NM_173537).

(iii) Our isolated cDNA clone resides in BAC RP11-219M8 (gb: AC124781), which subsequently influenced the naming of our gene to GTF2IRD2 $\beta$ (gb: AY312850) because it lies distal to the other GTF2IRD2 gene(s).

The genomic clones containing GTF2IRD2 and GTF2IR$D 2 \alpha$ appear to be overlapping in the sequence contig (see Figure 4); however, GTF2IRD2 $\alpha$ has two different aminoacid residues $(\mathrm{K} 39 \mathrm{E})$ and $(\mathrm{N} 514 \mathrm{H})$. These could be natural polymorphisms, in which case GTF2IRD2 and GTF2IRD2 $\alpha$ would represent the same copy of the gene. In contrast, GTF2IRD2 $\beta$ contains six nucleotide differences that, in addition to its location, distinguishes it from GTF2IRD2. These sequence differences lie at the C-terminus of the sequence resulting in amino-acid changes at residues 478 , $500,597,609,612$ and 812 (see Figure 3). None are truncating and do not affect the size of the predicted ORF, indicating that this copy may not be a pseudogene and is probably functional. In addition, like GTF2IRD2, putative TIRs were detected in the genomic region harbouring the GTF2IRD2 $\beta$ gene (one in intron 15-145 bp before exon 16 and one $\sim 3190 \mathrm{bp}$ after the $3^{\prime} \mathrm{UTR}$ sequence). cDNA clones for all the GTF2IRD2 variants described were identified suggesting that they are all transcribed in vivo.
In addition, a putative pseudogene (GTF2IRD2P, gb: AY312852) was predicted from genomic clone RP11-396K3 (gb: AC006995) and maps to the centromeric duplicated region flanking the WBSCR. GTF2IRD2P is a partial gene (ORF of 578 amino-acid residues) with a number of sequence variants including a deletion that results in a frameshift and consequently a premature stop codon. Database mining did not uncover any cDNA clones for the pseudogene.

Genomes of other mammalian species, sequenced to date, that contain the GTF2IRD2 orthologous genes include: Bos taurus, Sus scrofa, Felis catus and Papio cynocephalus anubis. No Drosophila, C.elegans or Fugu homologues were detected, indicating that GTF2IRD2 appears to be a mammalian-specific gene.

\section{Deletion status of GTF2IRD2 in WBS patients}

Somatic cell hybrid lines containing the deleted chromosome 7 homologues were prepared from four individuals with WBS and screened for the presence of the GTF2IRD2 gene by PCR analysis using locus-specific primers for intron 7 and intron 1, thereby, allowing selective amplification of GTF2IRD2. Primers that specifically amplify intron 1 of GTF2IRD2 $\beta$ were also used to determine the extent of the deletions. Two patients (WBS 27 and WBS 150) had deletions encompassing GTF2I and two (WBS 18 and WBS 99) had larger deletions extending to GTF2IRD2 (Figures 4, 5). Clinical descriptions of the patients deleted for GTF2IRD2 did not immediately highlight any phenotypic differences from the nondeleted cases, and all were described with 'classic' WBS phenotypes.

\section{Discussion}

We have identified a novel fusion gene, GTF2IRD2, characterised structurally by the presence of two Nterminal I-repeats and a C-terminal CHARLIE8 transposon-like element. ${ }^{22}$ GTF2IRD2 resides in the telomeric duplicated region flanking the WBS critical region and has at least three potentially functional full-length variants mapping to loci close to each other on chromosome $7 \mathrm{q} 11.23$. The mouse orthologue shows $80 \%$ homology to the human protein but is present as a single copy on chromosome 5G.

GTF2IRD2 is the third member of the TFII-I family of transcription factors (GTF2I and GTF2IRD1) to be described. ${ }^{6}$ All members reside on $7 \mathrm{q} 11.23$ and are characterised structurally by the presence of multiple I-repeats, each containing a helix-loop-helix-like domain. The Irepeat is thought to be involved in DNA and/or protein interactions. ${ }^{7}$ When considering the overall biological role of GTF2IRD2, its shared homology to the TFII-I family suggests that it may act as a transcription factor regulated by particular signalling cascades. ${ }^{6}$ However, GTF2IRD2 differs from the other TFII-I members because it has a 


\begin{tabular}{|c|c|c|}
\hline GTF2I & - - - - - MAQVAMSTLPVEDEESSESR - -MVVTFLMSALESMCKELAKSKAEVACIAVYET & 52 \\
\hline \multirow[t]{2}{*}{ GTF2 IRD2 } & - - - - -MAQVAVSTLPVEEESSSETR - -MVVTFLVSALESMCKELAESKAEVACIAVYET & 52 \\
\hline & 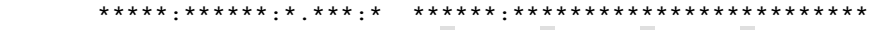 & \\
\hline \multirow[t]{2}{*}{ GTF2 IRD1 } & MALLGKRCDVPTNGCGPDRWNSAFTRKDEI ITSLVSALDSMCSALSKLNAEVACVAVHDE & 60 \\
\hline & 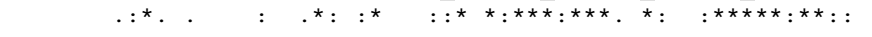 & \\
\hline GTF2I & DVFVVGTERGRAFVNTRKDFQKDFVKYCVEEEEKAAEMHKMKSTTQANR - - - - - -MSV & 104 \\
\hline \multirow[t]{2}{*}{ GTF2IRD2 } & DVFVVGTERGCAFVNARTDFQKDFAKYCVAEG- - - - LCEVKPPCPVNG- - - - - - MQV & 99 \\
\hline & 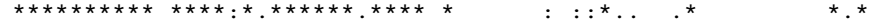 & \\
\hline \multirow[t]{2}{*}{ GTF2IRD1 } & SAFVVGTEKGRMFLNARKELQSDFLRFCRGPPWKDPEAEHPKKVQRGEGGGRSLPRSSLE & 120 \\
\hline & $\ldots * \star \star \star * * * \quad *: * * .:: * . * *:: * \quad$ * $\quad:$ & \\
\hline GTF2I & DAVEIET LRKTVEDYFCFCYGKALGKSTVVPVPYEKMLRDQSAVVVQGLPEGVAFKHPEN & 164 \\
\hline GTF2IRD2 & 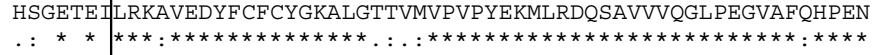 & 159 \\
\hline GTF2IRD1 & 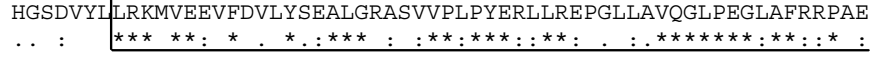 & 180 \\
\hline GTF2I & YDLATLKWILENKAGISFI I KRPFLEPKKHVGGRVMVTDADRS ILSPGGSCGPI KVKTEP & 224 \\
\hline GTF2 IRD2 & 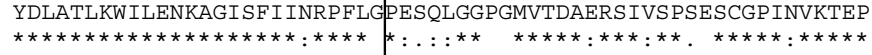 & 219 \\
\hline \multirow[t]{2}{*}{ GTF2IRD1 } & YDPKALMAILEHSHRIRFKLKRPLEDGGR - - DSKALVELNGVSLIPKGSRDCGLHGQAPK & 238 \\
\hline & 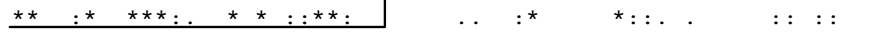 & \\
\hline GTF2I & TEDSGISLEMAAVTVKEESEDPDYYQYNIQAGPSETDDVDEKQPLSKPLQGSHHSSEGNE & 284 \\
\hline GTF2 IRD2 & 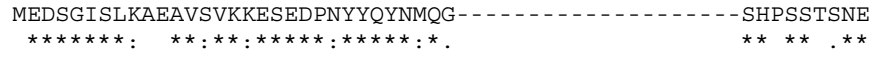 & 259 \\
\hline \multirow[t]{2}{*}{ GTF2 IRD1 } & VPPQDLPPTATSSSMASFLYSTALPNHAIRE-- - - - - - - - - - - - - - - LKQE & 273 \\
\hline & $\ldots: \quad \quad: \quad:: \quad . \quad \ldots \quad: \quad::::$ & \\
\hline GTF2I & GTEMEVPAEDSTQHVPS - ETSEDPEVEVTIEDDDYSPPSKRPKANELPQPPVPEPANAGK & 343 \\
\hline GTF2IRD2 & 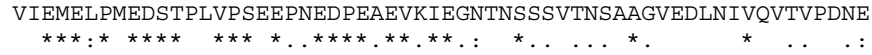 & 319 \\
\hline \multirow[t]{2}{*}{ GTF2 IRD1 } & APSCPLAPSDLGLSRPMPEPKATGAQDFSDCCGQKPTGPGGPLIQNVHASKRILFSIVHD & 333 \\
\hline & 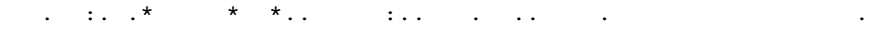 & \\
\hline GTF2I & RKVREFNFEKWNARITD RRKVEELFERKYAQAIKAKGPVTI PYPLFQSHVEDLYVEGLP & 403 \\
\hline \multirow[t]{2}{*}{ GTF2 IRD2 } & KERLSS - - - - - IEKIKQLREQVNDLFSRKFGEAIGVDFPVKVPYRKITFNPGCVVIDGMP & 374 \\
\hline & 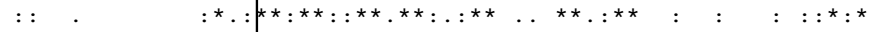 & \\
\hline \multirow[t]{2}{*}{ GTF2 IRD1 } & KSEKWDAFIKETEDINTLRECVQILFNSRYAEALGLDHMVPVPYRKIACDPEAVEIVGIP & 393 \\
\hline & 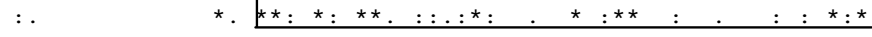 & \\
\hline GTF2I & EGIPFRRPSTYGIPRLERILLAKERIRFVIKK- - -HELLNSTREDLQLDKPASGVKEEW & 459 \\
\hline GTF2 IRD2 & 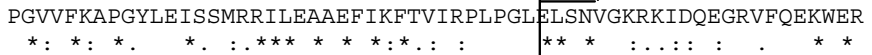 & 434 \\
\hline \multirow[t]{2}{*}{ GTF2 IRD1 } & DKI PFKRPCTYGVPKLKR ILEERHS I HF I I KRMFDER I FTGNKFTKDTTKLEPASPPEDT & 453 \\
\hline & $: \star \star: \star \quad: . \quad: \ldots \star \star$ & \\
\hline
\end{tabular}

Figure 3 TFII-I family protein alignments. ClustalW (1.82) alignments of the N-terminal regions of the human I-repeat containing proteins (TFII-I family). The residues implicated in the putative leucine zipper motif are highlighted in grey and the I-repeats are boxed. Full-length GTF2I (NM_016328) is used in this alignment alongside GTF2IRD1 (NM_016328) and GTF2IRD2 (AY312850).

C-terminal CHARLIE8 transposon-like region, the role of which is as yet unclear. Generally, transposases offer no selective advantage to the host and act merely to insert and excise themselves randomly from the genome. If, however, a transposable element inserts into a gene rather than a noncoding sequence the effects can be profound. Often the gene will be adversely disrupted, but in rare cases the transposase can insert in-frame and produce a viable protein. ${ }^{26}$ Such fusion proteins will either be lost from the genome during evolution or, if the fusion product provides the protein with novel functionality, it will be retained and have a biological role. ${ }^{22}$ This may be the case with GTF2IRD2, where the CHARLIE8 transposon has inserted itself in-frame creating a fusion gene, which is probably functional since it is highly conserved in mammals.

Although the CHARLIE8 transposase itself is unlikely to be active as an individual protein, the CHARLIE8-like element present in GTF2IRD2 appears to have retained a number of domains and motifs intrinsically linked to transposase ability - (i) a region with significant identity to the BED DNA binding domain; ${ }^{20}$ (ii) an atypical D,D(35)E domain; ${ }^{20}$ considered to be a crucial active site whose disruption results in loss of transposase ability. ${ }^{25}$ Partially 


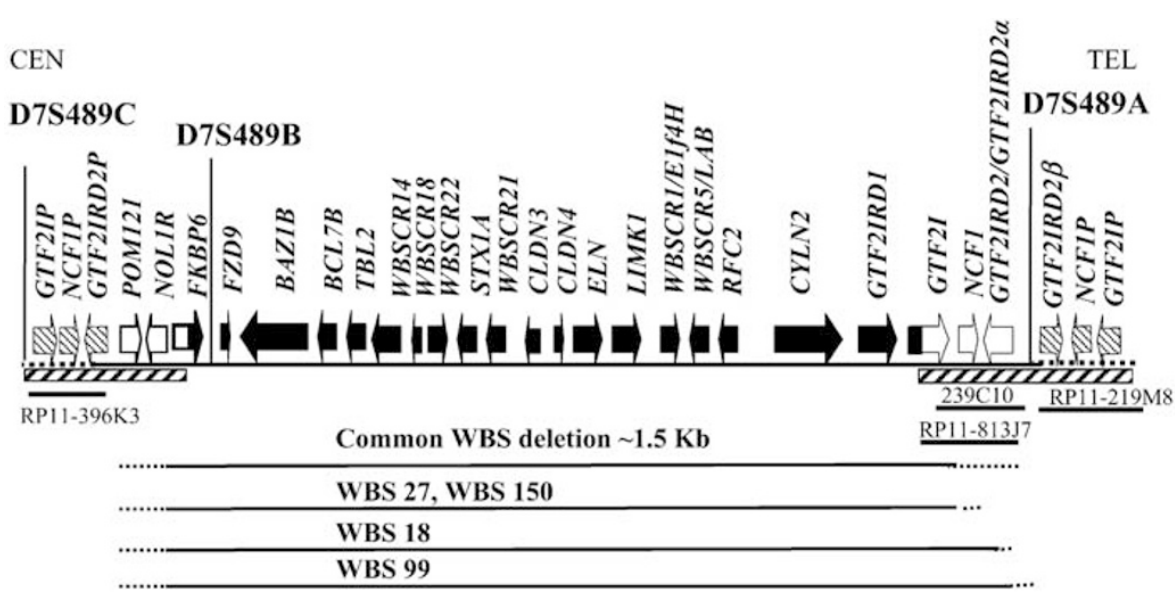

Figure 4 Transcript map of the WBS critical region showing the loci of the GTF2IRD2 genes and the extent of the deletions in some WBS individuals. Hatched boxes indicate duplicated regions. At the telomeric end, GTF2IRD2 and GTF2IRD2 $\alpha$ probably represent the same gene copy but they differ by two base changes/polymorphisms. The precise location of the WBS patient breakpoints within the duplicated regions is unknown. The location of the genomic clones containing the GTF2IRD2 genes are shown and the region is in a centromeric to telomeric orientation.

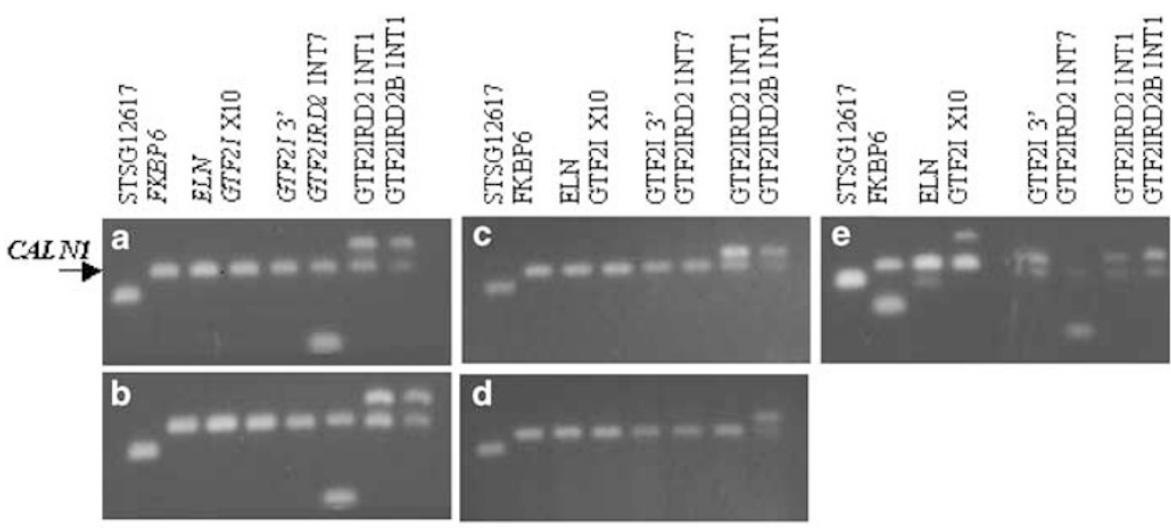

Figure 5 Deletion mapping of somatic cell hybrids. PCR analysis of somatic cell hybrids from the deleted chromosome 7 homologues of WBS individuals alongside a normal control. (a) WBS 27, (b) WBS 150, (c) WBS 18, (d) WBS 99 and (e) normal control. CALN1 is an internal nondeleted PCR control. Marker STSG12617 lies 2 Mb proximal to the WBSCR and is not deleted in WBS.

functioning atypical $\mathrm{D}, \mathrm{D}(35) \mathrm{E}$ domains have been observed in other proteins, for example, the Centromere protein B. CENP-B is a constitutive protein that has retained the ability to cleave single-stranded DNA on recognition of a highly conserved $17 \mathrm{bp}$ motif located at most mammalian centromeres (CENP-B box), but it lacks the ability to subsequently excise the fragment. ${ }^{27}$ The cutting action of CENP-B on DNA in the vicinity of the CENP-B boxes is thought to destabilise the region, promoting homologous recombination in 'hotspots'; (iii) a 'third region motif' essential for hAT transposase function $^{24}$ and (iv) two putative TIR sequences flanking the region thought to be the transposase insertion site.

The presence of these motifs suggests that the CHARLIE8-like region of GTF2IRD2 may have retained limited transposase functionality. This may just be the ability to interact with selected DNA or protein motifs, or may be more wide-ranging extending to strand cleavage. Alternatively, their presence may allow other MER1 elements to bind and cleave, resulting in regional instability. ${ }^{28}$ The presence of transposase target sites influencing the stability of a genomic region has been proposed as the pathological mechanism in Charcot-Marie-Tooth neuropathy type $1 \mathrm{~A}$ (CMT1A, [MIM: 118220]) and hereditary neuropathy with liability to pressure palsies (HNPP, [MIM: 162500]). Both conditions occur due to unequal crossover events between misaligned CMT1A-REP repeats flanking a $1.5 \mathrm{Mb}$ region on chromosome $17 .{ }^{29}$ Duplications at CMT1A-REP repeats residing on 17p11.2-12 cause CMT1A, while the reciprocal deletions are associated with HNPP. ${ }^{30}$ In all, $76 \%$ of 
crossover events in CMT1A and HNPP occur at a recombination hotspot containing a mariner-like element (MITE) flanked by a $36 \mathrm{bp}$ inverted repeat. ${ }^{30}$ Although MITE is not thought to encode a functional transposase, its presence is thought to influence the stability of the region by allowing other active transposases to bind and cleave the MITE TIR sequences. One can, therefore, envisage that the presence of transposase element target sites residing within the duplicated $7 \mathrm{q} 11.23$ regions harbouring the GTF2IRD2 genes could be a further factor influencing the instability of the region, by a similar mechanism to HNPP, making it more susceptible to gross chromosome rearrangements. Not all of these sites are conserved in the mouse Gtf2ird2 protein, indicating that it is less likely to have transposase activity in that species.

GTF2IRD2 is deleted in some WBS patients with the full spectrum of clinical phenotypes, but its role in the pathology of the disorder is not yet clear. Further studies will involve more detailed clinical and psychological analyses on these patients to determine whether any phenotypic differences exist that can be attributed to haploinsufficiency for this gene. In conclusion, GTF2IRD2 is a novel gene that could be involved in the pathology of WBS, and may also act as an element that undermines the stability of the critical region and, consequently, plays a role in promoting the unequal homologous recombination events underlying the WBS deletion.

\section{Acknowledgements}

This research was supported by the Wellcome Trust (Grant No. 061183).

\section{References}

1 Morris C: The natural history of Williams syndrome: physical characteristics. J Paediatr 1988; 113: 318-326.

2 Pober B, Dykens E: Williams syndrome: an overview of medical, cognitive, and behavioural features. Child Adolesc Psychiatr Clin N Am 1996; 5: 929-943.

3 Valero $\mathrm{M}$, de Luis $\mathrm{O}$, Cruces J, Pérez Jurado L: Fine-scale comparative mapping of the human $7 \mathrm{q} 11.23$ region and the orthologous region on mouse chromosome 5G: the low-copy repeats that flank the Williams-Beuren syndrome deletion arose at breakpoint sites of an evolutionary inversion(s). Genomics 2000; 69: 1-13.

4 Tassabehji M, Metcalfe K, Karmiloff-Smith A et al: Williams syndrome: use of chromosomal microdeletions as a tool to dissect cognitive and physical phenotypes. Am J Hum Genet 1999; 64: $118-125$.

5 Ewart A, Morris C, Atkinson D et al: Hemizygosity at the elastin locus in a development disorder, Williams syndrome. Nat Genet 1993; 5: 11-16.

6 Roy A: Biochemistry and biology of the inducible multifunctional transcription factor TFII-I. Gene 2001; 274: 1-13.

7 Vullhorst D, Buonanno A: Characterisation of general transcription factor 3 , a transcription factor involved in slow muscle-specific gene expression. J Biologic Chem 2003; 278: $8370-8379$.
8 Rice P, Longden I, Bleasby A: EMBOSS: the European molecular biology open software suite. Trends Genet 2000; 16: 276-277.

9 Thompson J, Higgins D, Gibson T: CLUSTAL W: Improving the sensitivity of progressive multiple sequence alignment through sequence weighting, position-specific gap penalties and weight matrix choice. Nucleic Acids Res 1994; 22: 4673-4680.

10 Wilkins M, Gasteiger E, Bairoch A et al: Protein identification and analysis tools in the ExPASy server; In: Link A (ed): 2-D proteome analysis protocols. New Jersey, Humana Press; 1998.

11 Bateman A, Birney E, Cerrut L et al: The Pfam protein families database. Nucleic Acids Res 2002; 30: 276-280.

12 Gattiker A, Gasteiger E, Bairoch A: ScanProsite: a reference implementation of a PROSITE scanning tool. Appl Bioinform 2002; 1: 107-208.

13 Altschul S, Madden T, Schäffer A et al: Gapped BLAST and PSIBLAST: a new generation of protein database search programs. Nucleic Acids Res 1997; 25: 3389-3402.

14 Nakai K, Kanehisa M: A knowledge base for predicting protein localization sites in eukaryotic cells. Genomics 1992; 14: 897-911.

15 Smit A, Green P RepeatMasker program, unpublished data.

16 Nielsen H, Engelbrecht J, Brunak S, von Heijne G: Identification of prokaryotic and eukaryotic signal peptides and prediction of their cleavage sites. Protein Eng 1997; 10: 1-6.

17 Emanuelsson O, Nielsen H, Brunak S, von Heijne G: Predicting subcellular localization of proteins based on their N-terminal amino acid sequence. J Mol Biol 2000; 300: 1005-1016.

18 Wilmot C, Thornton J: Beta-turns and their distortions: a proposed new nomenclature. Protein Eng 1990; 3: 479-493.

19 Ferré-D'Amar A, Prendergast G, Ziff E, Burley S: Recognition by Max of its cognate DNA through a dimeric $b / H L H / Z$ domain. Nature 1993; 363: 38-45.

20 Aravind L: The BED finger, a novel DNA-binding domain in chromatin-boundary-element-binding proteins and transposases. Trends Biologic Sci 2000; 25: 421-423.

21 Jurka J, Naik A, Kapitonov V: CHARLIE8 RepBase entry RepBase release 7.2. (Accessed 7th November 2002) 1998.

22 Smit A: Interspersed repeats and other mementos of transposable elements in mammalian genomes. Curr Opin Genet Dev 1999; 9: 657-663.

23 Smit A, Riggs A: Tiggers and other DNA transposon fossils in the human genome. Proc Natl Acad Sci USA 1996; 93: $1443-1448$

24 Calvi B, Hong T, Findley S, Gelbert W: Evidence for a common evolutionary origin of inverted repeat transposons in drosophila and plants; hobo, Activator, and Tam3. Cell 1991; 66: $465-471$.

25 Kulkosky J, Jones K, Katz R, Mack J, Skalka A: Residues critical for retroviral integrative recombination in a region that is highly conserved among retroviral/retrotransposon integrases and bacterial insertion sequence transposases. Mol Cell Biol 1992; 12: $2331-2338$

26 Esposito T, Gianfrancesco F, Ciccodicola A et al: A novel pseudoautosomal human gene encodes a putative protein similar to Ac-like transposases. Hum Mol Genet 1999; 8: 61-67.

27 Kipling D, Warburton P: Centromeres, CENP-B and Tigger too. Trends Genet 1997; 13: 141-145.

28 McCarron M, Duttaroy A, Doughty G, Chovnick A: Drosophila $P$ element transposase induces male recombination additively and without requirement for a $P$ element excision or insertion. Genetics 1994; 136: 1013-1023.

29 Kiyosawa H, Chance P: Primate origin of the CMT1A-REP repeat and analysis of a putative transposon-associated recombinational hotspot. Hum Mol Genet 1996; 5: 745-753.

30 Reiter L, Murakami T, Koeuth T et al: A recombination hotspot responsible for two inherited peripheral neuropathies is located near a mariner transposon-like element. Nat Genet 1996; 12: $288-297$. 